\title{
The Evolution of Criminal Interrogation Rules in China
}

Wei Wu and Tom Vander Beken

Wei Wu (Corresponding Author),

Institute for International Research on Criminal Policy (IRCP)

Ghent University

Universiteitstraat 4 - B-9000 Gent

Telephone: (00)32-(0)92646946

Fax: (00)32-(0)92646971

Email: Wei.Wu@Ugent.be

Prof. dr. Tom Vander Beken

Institute for International Research on Criminal Policy (IRCP)

Ghent University

Universiteitstraat 4 - B-9000 Gent

Telephone: (00)32-(0)92646939

Fax: (00)32-(0)92648493

Email: Tom.VanderBeken@UGent.be

Keywords

China, history, criminal justice, criminal interrogation, the right to remain silent, the privilege against self-incrimination 


\title{
The Evolution of Criminal Interrogation Rules in China
}

Wei Wu and Tom Vander Beken

\begin{abstract}
[Abstract]
This paper presents a historical analysis of Chinese legal theories and the evolution of criminal interrogation rules from the pre-Han to the reform era. A fuller understanding of the evolution of rules is doubtless relevant to the present day's controversy in China's legal reforms surrounding the right to remain silent during interrogation and the privilege against self-incrimination. The historical analysis reveals that the imperial social context which once morally legitimized judicial torture in Chinese criminal justice is very much alive even today. For future legal reforms in China, there are barriers in the current social context, which seem to be unconducive for the right to remain silent and the privilege against self-incrimination. But, traditional native resources are also available to legal reformers to ensure better protection of the rights of the suspect subject to police interrogation, and to eliminate police-coerced confessions.
\end{abstract}

\section{Introduction}

The agreement that we shall all have interrogation justice seems to be one of the few points of consensus in the pluralistic societies around the world (Ma, 2007). Within every criminal justice, we see various mechanisms ostensibly designed to constrain and shape the way in which the police exercise their questioning powers (Van Kessel, 1998). However, miscarriages of justice, such as wrongful detention, prosecution, and incarceration of the innocent, because of coercive and psychologically manipulative interrogation ${ }^{1}$ techniques arise both

\footnotetext{
${ }^{1}$ In many Western countries, there is a tendency to use the concept of "investigative interviewing" as an alternative to interrogation. For instance, in England, the expression "investigation interviewing" is used to describe questioning of suspects and victims, as well as witnesses at any point in the investigative process (Williamson, 1993; Gudjonsson, 1994). This change is a result of the combined effects of new legislation, psychological development, and organizational policies designed to make the questioning of suspect less inherently coercive. It is hoped that this ethical approach to investigation could elicit reliable information from a person about an alleged offence (Brewer and Williams, 2005). Indeed, as a result of these efforts, police questioning has come a long way. However, there is still a long way to go before the principles of investigative interviewing are reflected in standard police practice (Williamson, 1993, 98; Gudjonsson, 1994).
} 
in more adversarial and more inquisitorial types of process (Bedau and Radelet, 1987; Gudjonsson, 1992, 1994). The European Court of Human Rights (ECtHR) has condemned violations of "the right to remain silent under police questioning and the privilege against self-incrimination" everywhere, in Great Britain as well as on the continent ( $\mathrm{Wu}, 2011)$. In the People's Republic of China (PRC), the problem of police-coerced confession is also one of the most intensely criticized aspects of the Chinese legal system (Wu \& Vander Beken, 2010).

For obvious reasons, obtaining information on the extent of coercion exerted in extracting a confession for a criminal investigation is nearly impossible. According to the fourth report from the Chinese government to the United Nations Convention Against Torture and Other Cruel, Inhuman or Degrading Treatment or Punishment (CAT), between 1999 and 2004², 566 persons, involved in 541 cases, were sentenced by extorting confessions through torture ${ }^{3}$. However, Ma and Peng (2006: 22) consider that official statistics document only the tip of the iceberg, implying thereby that forced confessions occur with greater frequency than officially reported. Many Chinese scholars, relying on different sources like interviews with present and former law enforcement officers or individual field observations, have made the alarming assertion that the malady of confessions produced by torture ${ }^{4}$ (xingxunbigong 刑讯逼供) has been widespread in China (Wu and Vander Beken, 2010). Notably, the problem of interrogation practices has been so pernicious and pervasive that it captured the attention of not only the domestic academic community, but also of the

\footnotetext{
${ }^{2}$ Chinese version of the fourth periodic report, pages 36-40.

${ }^{3}$ Article 1 of the United Nations Convention Against Torture and Other Cruel, Inhuman or Degrading Treatment or Punishment (CAT) is the first provision in an international treaty that defines torture, and separates illegal practices into two categories: (i) torture, and cruel, inhuman, or degrading treatment (ii) punishment which does not amount to torture. According to this definition, to classify an act as torture, the pain of suffering inflicted must indeed be severe.

${ }^{4}$ The Chinese academics define torture in a broader sense than the CAT does. They define torture as any act by which corporal treatment or quasi-corporal treatment is inflicted on a suspect or a defendant to extract confessions by judicial officers (Zhe, 2005). Corporal treatment refers to physical coercion, inflicting pain directly on the body, such as beating or imparting electric shock. Quasi-corporal treatment refers to physical or psychological coercion, inflicting pain (physical or mental) indirectly on the body, such as through sleep deprivation, exposure to cold or heat, or forcing one to sit or stand in uncomfortable positions.

In fact, some studies have shown that in the current era the interrogation practice in China has moved away from brutally scarring violence towards more time-consuming and 'clean torture' (Wu \& Vander Beken, 2010, 561).Notably, the history of American police interrogation also shows an evolution from more brutal forms of interrogation toward a mainly psychological oriented approach of interrogation (Leo, 2008). While the 1931 Wickersham Commission Report and Miranda appear to be partly responsible for the dramatic decline in violence in the American interrogation room from the 1930 s through 1960 s, it is argued that American police have also become skilled at the practice of manipulation and deception during interrogation (Leo 1992).
} 
international community. Scathing reports from Non-government Organizations (NGOs) and other overseas human rights institutions observe that torture has been widespread and systemic ${ }^{5}$. Human rights activists complain bitterly that the judiciary lacked independence, because the party-state politicized criminal cases and employed torture for oppressing political dissent. Noting that the Chinese criminal procedure, particularly the one for interrogation, is inconsistent with the privilege against self-incrimination and the right to remain silent, the rights activists urge the PRC for compliance with the "universal" norms ${ }^{6}$.

While not denying that much remains to be done, the Chinese government is not happy with the foreign critics for discounting the progress it made in the promotion and protection of human rights, including its efforts to combat torture, and for exaggerating the severity of the problems by focusing on the relatively few cases involving political dissidents ${ }^{7}$. On the other hand, acknowledging that involuntary confession in criminal investigations remains a serious problem, it has taken various steps to address it, including reforming its procedural law and educating police officials about the importance of due process. Indeed, although China was governed largely as a "lawless" state in the first three decades after the founding of the PRC, the past 20 years witnessed significant changes in the Chinese criminal justice landscape which sets restrictive standards for police behaviour and provides procedural safeguards to suspects subject to police interrogation. Nevertheless, the government still feels uneasy about some "undeniable" principles in western criminal procedures, such as the presumption of innocence and the privilege against selfincrimination (Gelatt, 1982; Ren, 2007). The officials in the legal committee of the Standing Committee of the National People's Congress explained that the Chinese approach to criminal investigation is not to engage either in the "presumption of guilt" or in the "presumption of innocence" (Man and Li, 1999: 63). The Chinese criminal procedure does not presume anything-it lets evidence and facts speak for themselves (Gelatt, 1982). Stressing on reliable evidence and strict prohibition on extracting confessions by torture, the revised criminal procedure law (CPL) in 1996 continues to adopt the principle of "taking facts as the basis and law as the criterion" (CPL, Art. 6) and to encourage

\footnotetext{
${ }^{5}$ See, for instance, http://www.amnesty.org/en/library/asset/ASA17/094/2008/en/bb7a7607-8f0b-11dd-8d033f760a3cc4a3/asa170942008en.pdf and http://www.falunhr.org/reports/PDFs/ShadowReportOnChina2008.pdf.

${ }^{6}$ The rights activists argued that there is a significant level of consensus regarding "the presumption of innocence" and "the privilege against self-incrimination" as set forth in the Universal Declaration of Human Rights (UDHR) (Art. 11), and the International Covenant on Civil and Political Rights (ICCPR) (Art. 14) (Gelatt, 1982).

${ }^{7}$ Comments by the Government of the People's Republic of China to the concluding observations and recommendations of the Committee against Torture (CAT/C/CHN/CO/4).
} 
suspects to "answer questions asked by investigators truthfully"8 (CPL, Art. 93) to achieve truthful and fair justice.

In fact, the Chinese government's position is by no means universally shared. The majority view among Chinese legal scholars is that pernicious interrogation is closely related to China's pre-trial inquisitorial investigation with its implicit acceptance of police power to detain and interrogate suspects (Zuo 2005; Chen 2006). Hence, many Chinese academics have increasingly looked to the right of remaining silent and the privilege against self-incrimination as the basis for restricting the questioning power of the police and for pressing law enforcement to shoulder most of the load by collecting objective evidence of the crime charged (Ning, 2002; Wan, 2006). Although there have been many legal attempts to establish the right and the privilege, there is currently a growing scepticism in the academic world if the apparently successful experience of the West with "due process", and an accusatorial system in which defendants are privileged to remain passive, can simply be copied as an independent standard in the Chinese context (Cui, 2001; Ma and Peng, 2006). According to Peerenboom (2004: 1073), transplantation of laws which are at odds with China's current conditions or which are based on fundamental values that are not shared by the majority of Chinese citizens, diminishes the likelihood of getting the reforms adopted or, even if they are adopted, they will not be implemented. This observation seems to be confirmed by the fact that despite significant revisions to the Criminal Procedure law in 1996, the police's abuse of questioning power, such as coercing for confession, illegal detention and denying lawyers' access to their clients, remains pervasive in practice (Lin, 2005).

This paper presents a historical analysis of Chinese legal theories and the evolution of criminal interrogation rules from the pre-Han to the reform era. A fuller understanding of the evolution, besides being desirable for its own sake, is definitely relevant to the present day's controversy surrounding the right to remain silent and the privilege against self-incrimination. The purpose of the historical analysis is twofold. On the one hand, by exploring the historical, political, and philosophical backdrop of current reforms, it is easier for (Western) legalists to understand how the right and the privilege in China develop along a different path. On the other hand, only after understanding China's legal traditions, can one begin to ascertain what traditional native resources are available to reformers, and what obstacles are they likely to encounter in trying to establish the right and the privilege, given China's past.

\footnotetext{
${ }^{8}$ Eliciting reliable information from a suspect is a complex process in which both the interviewer and interviewee play integral roles. Ultimately, the quality of any police interview is determined by a wide range of interrelated factors (Brewer and Williams, 2005, 11). Nonetheless, Chinese lawmakers believed that cooperative interviewing styles rather than a confrontational style of interviewing could best lead to accurate information and confessions.
} 
This paper is structured as follows. The first section documents the rise of Confucianism and legalism during the Spring and Autumn period (770-476 B.C.) and illustrates their legal implications. This is followed by an analysis of the "legalization of Confucianism" process in Chinese society following the Qing's fall (221-206 B.C.). The paper will then focus on the Tang dynasty (618-907) and discuss the interrogation model laid down by the Tang Code which thrived until the early twentieth century. Next, after tracing the ideological evolution in China in the turbulent period before the birth of the PRC, the interrogation rules under the Mao era will be examined. In the following section, the questioning rules and their operation in the reform era are discussed, as also the social and political context underlying them. The last section presents the conclusions.

\section{Classical Legal Theories}

The era of the Spring and Autumn period (770-476 B.C.), though characterized by interstate warfare with many Chinese in despair, was intellectually one of the most productive eras in Chinese history. Many philosophers propounded various theories. From these theories, two major schools of thought-Confucianism and legalism - eventually emerged, and they remained central to Chinese legal thought down to the twenty first century.

\subsection{Confucianism}

\subsubsection{Shame, Self-examination and Self-cultivation}

Confucianism was first conceived and developed by Confucius (551-479 B.C.), when he was an itinerant teacher. In his theories, Confucius adhered to the premise that humans are essentially good by nature and that their good qualities can be brought out through education (Terrill, 2003; Chen 2004). The ultimate goal of Confucian's personal cultivation was to achieve self-perfection, as represented by the concept of ren (benevolence, 仁), which means becoming the most genuine, most sincere, and the most humane person one can be ( $\mathrm{Tu}, 1979)$. This process of self-perfection requires self-discipline and the observation of $l i^{9}$ (ritual propriety, 礼) (Analects, 12:1). Through internalization of $l i$, individuals will develop a sense of shame when they have done something wrong. Moreover, shame will direct the person inward for self-examination, and motivates the person toward socially and morally desirable changes (Analects, 2:3). Thus, admitting one's misconduct and desiring to change oneself, which is believed to be an act of expiation requiring personal courage, is a virtuous sensibility that a Confucian values and fosters (Fung, 2006).

\footnotetext{
${ }^{9} / i$ is essentially a set of ethical norms that provide guidance for appropriate behaviors in all circumstances of life, spanning from ordinary daily activities to special ceremonies, prescribed on the basis of a person's social status (Kaempfer, 2006).
} 


\subsubsection{Community, Deviance and Contrition}

Confucius made it clear that $l i$ is and should be based on human nature and universal reasons (Ma, 1987). Though human relationships are manifold, Confucius emphasized the society's "natural" relationships. He said: "Let the monarch be a monarch, and the minister a minister. Let the father be a father, and the son a son" (Analects, 12:11). Put differently, each individual should act in accordance with his role in life. Mencius (372-289 B.C.), an important philosopher of early Confucianism, elaborated the content of each relationship that must be jointly realized by both the parties concerned: "Affection between father and son, righteousness between ruler and minister, separate functions between husband and wife, precedence of the old over the young, and fidelity between friends (Mencius 5)". Considering the relationships separately, the elaboration consists in the father being merciful and the son filial, the ruler being a leader by superior virtue and the minister a loyal follower, the husband being upright and the wife complaisant, the elder brother being caring and the younger brother complying respectfully, and friends being faithful to each other. Seen in this perspective, Confucianism is decidedly paternalistic with each relationship carrying obligations of respect and submission by its members. Nonetheless, Confucian's relationships also stress a sense of reciprocity (bao, 报), that is, those who have increased authority shall also have increased responsibilities (Johnson, 1995).

Confucius taught that one of the superior's responsibilities is to be the role model for the subordinates (Analects, 2:19, 8:2). The personal moral aspiration of achieving ren is an early and ongoing process which can be achieved only through communal participation and efficacious communications. Importantly, to Confucius, those who are engaged in such moral education can best do so by setting themselves as personal examples (Ma, 1987; Windrow, 2006). By so doing, the superior inspires the subordinates with virtues and prevents them from crossing the social deviance line into criminal activity. Ultimately, the benefits of proper behaviour would diffuse throughout the society and strengthen social harmony (Peerenboom, 2002).

Under these communitarian social conditions, individuals, almost always, find themselves belonging to a closely integrated group that reflects their honour or shame. More specifically, when people achieve well, the entire community shares the honor. Likewise, when people fail, they do not lose just their own face (mianzi, 面子), but of all those around them (Wilson, 1980, 1981). Apparently, shame, in Confucian communities, is a group concern, rather than an individual concern ( $\mathrm{Hu}, 1944)$. This group concern and mutual "interest" also ensure interdependency and reinforces mutual obligation and supervision among neighbours. 
Apart from this, in the light of the Confucian belief in humanity's capacity for moral improvement through education, shaming is also used as a mechanism in reforming wrongdoers - what might today be labelled as rehabilitation or reintegration. As mentioned earlier, shame is primarily related to morality; so, people would show anger or even extreme rage toward those who commit shameful acts (Lu, Zhang and Miethe, 2002). Nevertheless, from a Confucian perspective, even though shameful acts generate anger in people, the wrongdoer's showing a sense of shame and admitting his guilt signal that he realizes his moral faults. They also demonstrate that one promises to reform oneself and seeks reconciliation with the larger community, thereby displaying socially "engaging emotions" (Kitayama, Markus \& Kurokawa, 2000). This would result in forgiveness commensurate with the degree of contrition.

Because Confucians stressed using shame to mitigate deviancy and resocialize individuals, they regarded the codification and public dissemination of laws sends the wrong kind of message (Peerenboom, 2002; Windrow, 2006). According to Confucius, laws, backed up by punishments, may induce compliance in the external behaviour of society members, but they are powerless to change their inner character (Analects 2:3). Theoretically, this view leaves little room for the operation of codified law and punishment. On the contrary, it constitutes a sphere of informal social control operating on a familial or communitarian basis through moral persuasion and social education.

\section{$2.2 \quad$ Legalism}

Confucian was rivalled from the very beginning. Legalism that had arisen during the early Warring State period (475-221 B.C.) advocated a social control program which was in direct conflict with Confucian ideals. In the legalistic view, human beings are naturally greedy and selfish. Thus, virtue cultivation and moral examples are inadequate to maintain the social order because people's base instincts will constantly drive them to wrongful behaviour (Ren, 1997). The only way to make them behave correctly and to achieve a wellordered society is by an impartial system of rewards and punishments. Specifically, legalists advocate centralization of authority in the ruler through creation of a vast bureaucracy and extensively written laws, and the use of harsh, universally enforced penal code to ensure compliance with state policy. They believe that if even minor infractions are ruthlessly punished, then no one will dare to commit serious crimes (Shang Jun Shu, 17:3).

In theory, the ruler remains the ultimate authority. Han Feizi (281-233 B.C.), a prominent philosopher of legalism, advocated that the ruler should use $F a$ (law, 法), shu (tactic, 术) and shi (power, 势) to govern his subjects (Peerenboom, 2002). It is seen clearly that legalistic law is one of the means to serve the interest of the ruler, not necessarily the common people. 


\section{Two Legal Theories Combined: Legalistic Bureaucracy to Enforce Confucian Norms}

The Zhou dynasty (1046-256 B.C.) maintained fairly effective control of China for a few generations, but then gradually lost its grip. After 770 B.C., real power was divided among a number of states. During the war period, Qin State's minister, Lord Shang (390-338 B.C.), overhauled the state according to legalistic ideas. His legalism-inspired reforms deployed a detailed penal code through an elaborate, tightly controlled bureaucracy to ensure efficient control in the hands of the ruler (Bary, 1995). These reforms, together with other favoured agricultural policies, successfully bolstered the state's power. Finally, Qin state unified China and established the Qin Empire (221-206 B.C.).

Unsurprisingly, the Qin dynasty lasted less than twenty years. Although the ruthless rule of Qin brought its speedy downfall, the succeeding Han dynasty's emperors, facing tremendous pressure to consolidate their rule in such a large territory, retained the Qin's essential legalist apparatus for central administration (Windrow, 2006).

Noticeably, the Confucian intelligentsia at that time started to explore the relationship between Confucian $l i$ and legalist $f a$ (law). In a similar thought shift, Dong Zongshu (179-104 B.C.), a Han Confucian, integrated legalist and YinYang school of thought to create his own Confucian doctrines. He overhauled the standard interpretation of the Confucian classics and advocated combining the functions of $l i$ and law ( $f a)$ by emphasizing the supremacy of $l i$ and the subservience of law. On the presumption of the operations of Yin (阴) and Yang ( 阳), he further emphasized the emperor's sacrosanct power in governing the state and in enacting laws. Simply put, this shift in Confucian thought legitimized the use of bureaucracy, recognized the role of law and punishment, and helped to uphold the superiority of the emperor (Ma, 1987). Eventually, Emperor Wu (157-87 B.C.) adopted Confucianism as the official orthodox doctrine.

Since then, Confucian's moral standards started to become a part of the content of law, and criminal code became the instrument for executing such content. In addition, on the ground, as the people trained in Confucianism began to take on adjudicatory positions in the government, Confucian thought shaped Han's administration (Windrow, 2006). Even after the Han dynasty's fall in 220, successive dynasties continued to accelerate the Confucianization of the legal code. Perhaps most importantly, the Tang Code, first issued in 637 and last revised in 737 during the Tang dynasty (618-907), represents the final synthesis of legalist and Confucian ideals begun centuries before (Ma, 1987, 673). 


\section{The Criminal Interrogation Rules under the Tang Code}

The Tang Code is characterized by Confucian's moral standards (li) and its penal attribute. The Code's preamble states that the primary aim of the law is to maintain human order as coordinated with the cosmic order of Heaven and Earth. In other words, the ruler's remedial use of law is to redress human disorders and restore the proper balance between man and nature. Hence, if a crime happens, the truth has to be discerned so that the state could administer appropriate punishments ${ }^{10}$ and restore social harmony (Ren, 1997, 31). Because of this assumption, finding factual guilt, which insists on the offender's voluntary or coerced admission of guilt and repentance of the crime, is an almost indispensable element for concluding criminal cases before the courts (Tang Code, Art. 476).

Therefore, undergirding the interrogation procedure of the Tang trial was a set of rules whose purpose was to persuade or oblige the accused to respond or confess to the charges against him.

\subsection{The Structure of an "Accused Speaks" Trial}

The criminal case was first investigated, prosecuted and tried by a district magistrate ${ }^{11}$ who was both the judge and chief administrator of the region. In fact, the Confucian family concept was extended to judicial and governmental affairs, where the district magistrate was called 'parent' officer (fu-mu guan, 父 母官) with presumably good moral characteristics, such as benevolence and impartiality, and superior wisdom (Alford, 1984). As Ren (1997: 25) put it, "the government was not a public servant body, but a sacrosanct paternity".

The structure of the trial inquiry can be described as paternalistic when historical sources allow one to see how a Chinese imperial criminal trial was conducted. Generally, at trial, both the accused and the accuser were required to kneel on the ground in front of the magistrate who was assigned the responsibility of ferreting out the facts (Gelatt, 1982). The accused, with no aid of a counsel, replied insistently to the questioning and to the testimony of the accusers. Moreover, the magistrate, as an authority in a leading position, could

\footnotetext{
${ }^{10}$ Penalties in imperial China were designed to fit the criminal, not the crime (Ansley, 1986, 171).

11 Like all dynasties since the Qin, the Tang government operated through its bureaucracy, brimming with officials who had passed the imperial examinations based on the Confucian Classics (Windrow, 2006).
} 
control the content and direction of the interactions for his purpose (Chang, 2004).

\subsection{Confession by Persuasion}

As observed above, the questioning session in courtrooms permitted the magistrate to control and extend the questioning sequences as he deems necessary to extract the desired response. Suspects, by contrast, were required to interactively respond to the questions asked. Responding to these pressures, the guilty would often resort to lies to escape conviction. Though this frequently instinctive desire of the guilty to play the innocent was recognized, the Tang's trial was not concerned about exposing the magistrate to the suspect's dubious statements. On the contrary, the Code provided that the magistrate should sit back at the beginning of the case and expect that evidence damaging to the suspect would come out of his altercation with the accuser and witnesses (Art. 476). It was believed that precious information can be obtained even from false denials of guilt, inconsistencies, and other verbal and non-verbal expressions emanating from the suspect $(\mathrm{Zu}, 2008)$. In addition to the special attention given to the time sequence of the questioning, the Code went on to specify that both the accused and the accuser's statements should be verified to the extent feasible (Art. 476). Thus, for example, if a suspect confessed to a murder, he was supposed to be asked where he put the weapon. If he said he threw it into the river, the magistrate was supposed to send someone to find it, so that when fetched, it could corroborate the confession.

Eventually, if the suspect managed to prove to the magistrate's satisfaction during the course of the interrogation that he was innocent and had been falsely accused, one way to maintain proper balance of social harmony was to punish the accuser for the crime of false accusation (Gelatt, 1982). On the other hand, if the suspicions were established, the suspect would be greatly shamed or criticized to make the 'offender' feel ashamed of his crime and persuade him to change his mind, repent and admit to the crime facts (Ren, 1997; Chang, 2004). The Chinese literature, arts and folklore often tell that the magistrate talked loudly, powerfully, and fiercely to urge on the reluctant suspect to confess.

\subsection{Confession by Judicial Torture}

Judicial torture, at least in theory, was reserved as a last resort for those who were under strong suspicion, but chose to defy confession of their moral faults (Tang Code, Art. 476). It had been long recognized by Chinese lawmakers that the agony of torture may induce the innocent to confess things that they never $\operatorname{did}(\mathrm{Zu}, 2008)$. Hence, a highly detailed set of rules governing the application of torture was put forward by the Code to enhance the reliability of tortured confessions and to acquit the innocent. First, the torture practices were permitted only in cases where the evidence strongly tended to establish the suspect's guilt. 
As observed earlier, Article 476 of the Code lays down specific procedures regarding interrogation, such as the confrontation between the accused and the accuser, and the co-examination of objective evidence. By and large, the magistrates were not vested with discretionary powers; they were required to strictly enforce the statutory rules (Alford, 1984; MacCormack, 1987). Hence, violations of these rules by magistrates carried a punishment of sixty strokes with a wooden stick (Tang Code, Art. 476). Second, magistrates needed prior approval of higher officials for torture decision. (Tang Code, Art. 476). Third, the types of torture were limited to whipping or beating with a bamboo strip or wooden stick, and adjusted depending on the suspect's responses during the examination. The Code provided that the torture should not exceed 3 applications, with an interval of 20 days; the number of whippings or beatings should not exceed 200 in total. If the suspect refused to confess even after these beatings, he should be released subject to obtaining a guarantor pending the trial (Tang Code, Art. 477). Presumably, 20 days for repentance or confession was considered reasonable for individuals to 'reflect on' their acts. This also can be seen as another example of the law makers' intent to deter undesirable social behaviour and to change the wrongdoer's mind.

\subsection{Factual Guilt}

All this clearly implies that the essential purpose of the criminal interrogation at the Tang trial was not finding the legal guilt of crime by using legally admissible statements against the accused, but, rather, discovering the factual guilt through the offender's confession and making the wrongdoer morally shameful and remorseful. The judicial torture, which, together with the confession reward policy ${ }^{12}$, was lenient to those who complied with the government, fortified the wrongdoer's deference to legal authority.

\subsection{A Stable Model for Centuries}

Through the interplay between Confucian moral standards and legalist's bureaucracy, this 'persuasive' interrogation model of the Tang Code proved astoundingly stable by thriving until the early twentieth century.

On the one hand, rather than simply enforcing an arbitrary set of government-defined criminal procedures, the interrogation rules noticeably reflected social norms which were already pervasive, providing legal enforcement with powerful social legitimacy. In fact, after Confucianism became the official orthodox doctrine in China, families who were affluent enough to practice it engaged private tutors to teach their children Confucianism.

\footnotetext{
12 The Tang Code provided detailed statutory clarifications of penalty reduction or remission for offenders who confessed or surrendered voluntarily according to the seriousness of their offences (Rickett, 1971; Ren, 1997).
} 
Schoolboys were also required to learn the entire Analects by heart (Grant, 1989). Among the poor families, Confucianism was passed on by parents or other adults from generation to generation (Jiang, Lambert and Wang, 2007). Therefore, there is good reason to believe that Confucianism's moral standards, particularly those dealing with contrition, patriarchal relationships and familial obligations, were to some extent internalized within Chinese citizens. Meanwhile, as observed earlier, since the Han dynasty, Confucian doctrines also served as the guiding light to define what might or might not become a matter of law and govern the administration of criminal penalties. The consensus between law and morality often indicates that what the state seeks to enforce by compulsion corresponds largely to the sense of right and wrong of the society in general (Ren, 1997). The judicial torture could be regarded as an extreme case in which law and morality become one-what Confucianism morality 'forbids', the law 'punishes'. To Westerners, it is fundamental to human liberty that individuals cannot lawfully be required to answer incriminating questions that will aid in convicting them for a crime (Helmholz, 1997). The imperial Chinese may regard submission to legal authority and repentance for unlawful behaviour as valuable virtues (Lu and Miethe, 2003).

On the other hand, perhaps more importantly, this 'persuasive' interrogation model could survive over a millennium in imperial China, not only because there was a social consensus between law and morality, but also because of its inherent connection with the increased imperial hierarchical powers. As already suggested, Confucian codes of morality (li) such as filial piety and loyalty were enforced by legalist's $(f a)$ reward and punishment machineries. In this way, the throne, through unrelenting fortification of familial and social hierarchies, transformed the family into a de facto extension of the bureaucratic state (Windrow, 2006). Indeed, members of society that held relative power in informal positions, such as father and brother, had an interest in maintaining the social order through the mediation of conflicts, because the restoration of order granted them power and prestige over their subordinates. Moreover, imperial law unequivocally gave the parents extended rights, ranging from physical punishments to commanding their child's suicide for moral causes (Ren, 1997, 27). The result in theory, and to a remarkable degree in practice, was a system designed to educate wrongdoers in a subtly graded way, which began with the minor 'punishment' usable by fathers to force their children to confess and recognize their moral faults. It was then passed on to the minor but sometimes different devices available to intervening authorities, and finally ended with the potential application of more severe torture by the formal legal authority. This complex gradation ensured that informal, socially-based enforcement of social norms occurred continually and finally fortified people's deference to authorities, leading ultimately to consolidation of power in the hands of the throne. Under this social structure, district magistrates, members of the real ruling class of the society, could maintain their enormous power and authorities in courtrooms. In contrast, criminal suspects were put in a disadvantageous 
position both interactively and socio-culturally. Hence, magistrates could fully exercise, as interrogators, their interactive power to humiliate and attack criminal suspects' moral senses, or even torture them, to elicit confession and remorse.

\subsection{Actual Operation and Legitimacy "Crisis"}

Although the imperial criminal justice encompassed a broad range of procedural and administrative measures ${ }^{13}$ designed to convict the guilty and acquit the innocent, and to limit the extent and degree of torture that could be applied, it does not, of course, mean that such results were regularly reached or that the magistrate's discretion was always properly controlled. True, the moral rhetoric tells that criminal questioning in the courtroom was designed to teach, humble, and extract contrition form wrongdoers. However, in reality, in the absence of the kinds of procedural protections afforded by a formal legal system, good magistrates, learning well in the Confucian Classics but not abusing their powers, were episodic and unpredictable. In fact, numerous studies have shown that torture was widely abused by magistrates in practice as a "short cut" to end cases $(\mathrm{Zu}, 2008)$. Langbein (2004: 101) captures the matter with great insight, observing that "once legitimated, torture could develop a constituency with a vested interest in perpetuating it". In addition, as Langbein (2004: 101) further pointed out, "history's most import lesson is that it has not been possible to make coercion compatible with truth". If the magistrate engaged in suggestive questioning and the accused knew something about the crime but was still innocent, the accused might yield to the pain and torment and confess to things that he never did (Langbein, 1977, 2004). Cases arose repeatedly in which the real guilty person was detected after an innocent had confessed under duress and been convicted and executed ( $\mathrm{Zhu}, 2005)$.

\subsection{Late Imperial China}

On a more macro level, the lack of effective institutional constraints on the ruling elites, especially the throne, left the interest of the whole Chinese society or the state's destiny largely at the mercy of those in power. Besides, good emperors having both great moral achievements and extraordinary political insight were also episodic and unpredictable. Under the Tang (618-907) and Song (960-1279) dynasties, China was among the leading cultures of the world, far superior to Europe in wealth, technology and science (Moise, 1994). However, by the time of Ming dynasty (1368-1644), China had gradually fallen

\footnotetext{
${ }^{13}$ The accused or the family of the accused virtually had unlimited scope to register their protest against a decision to higher authorities through an appellate procedure. Parties could even take their case all the way up to the emperor (Alford, 1984). If magistrates were found to have rendered wrong judgments, they and even their higher officials would be punished according to a complex liability system (MacCormack, 1987).
} 
into decline. In the early $17^{\text {th }}$ century, when the British were moving ahead with capitalism, China was just then in the final years of the Ming dynasty characterized by internal chaos and a ban on maritime trade and interaction with foreign countries. By the middle of the $19^{\text {th }}$ century, the continuous isolationist policy adopted by the Qing dynasty (1644-1911) was beginning to break down in the face of European military threats.

After several failures against foreign military attacks, especially the failure of the Boxer Uprising in 1900, Empress Dowager Cixi (1835-1908) - who was under the impression that Chinese civilization was superior to all other civilizations of the world-was shocked to realize and finally accept the necessity of changing the mode of governance in accordance with the changing circumstances to stay in power. Hence, New Policies (xinzheng, 新政) were initiated and the revision of the legal system was a part of it. Spurred further by foreign pressures and highranking officials, who were anxious to abolish the feudal extraterritoriality, legal reform progressed remarkably fast. Thus in 1904, the Bureau of Legal Codification was established to draft a new series of code, including the criminal and criminal procedure law. Shen Jiaben (1840-1913), the co-director of the Bureau, was particularly instrumental in the drafting of the new laws. Shen, combining Confucian ethical norms with German and Japanese models of punishment and due process, hoped to revive the ideal of a benevolent government (renzheng, 仁政) that punishes lightly (xingqing, 刑轻) and forbids extracting confessions under torture (Dikötter, 2002). It was Shen and his colleagues' efforts, in January 1911, that made the government put into effect the "New Penal Code of the Great Qing". Although some legalists considered this code 'conservative' with Confucian legal tradition preserved in numerous articles, the dominant view still seems to be that it is an important landmark in China's legal modernization (Wang, 1997). In this legal document, corporal punishments and extracting confessions by torture were outlawed.

However, the first wave of legal modernization could not take root during the turbulent period, following the Qing dynasty's collapse. Three years later after Cixi's death, the Qing dynasty was overthrown by the Wuhan Uprising on October 10, 1911. The establishment of the Republic of China in 1912 by the Nationalist Party (known as the Guomindang or GMD) aroused high expectations, but within about five years, the central government collapsed completely ${ }^{14}$, and China slipped into an unstable period of warlord factionalism, imperial Japan's invasion, and a civil war between GMD and the Chinese Communist Party (CCP) from 1946 to 1949.

\footnotetext{
${ }^{14}$ Although most of China came under the control of the GMD during the Nanjing period (1927-1949), political control of the entire region remained in the hands of warlords. As Zhu (2007: 536) observed, "the GMD's unification of China was more symbolic than real".
} 
Noticeably, an iconoclastic tendency, aimed at destroying the Confucian legal traditions, was also advanced during this turbulent period (Ma, 1987). The "legalization of Confucianism" by imperial thrones unfortunately brought disrespect and even 'damage' to both law and Confucianism. As explained, Confucius's belief was that wrongdoers could reform themselves by contrition, enlightment, and education. Therefore, Confucius would be the last person to approve of "compulsory" morality by torture and corporal punishments. However, owing to the harsh criminal procedure and punishment designed to uphold Confucianism's moral standards, not only was imperial Chinese law made largely inhuman, but also Confucianism's inherent humanity was challenged. Consequently, with the downfall of China's two-millennia-old imperial system in 1911, Confucianism not only lost its official status as the state orthodoxy but was also undermined as a "feudal ideology" by both the GMD and the CCP.

\section{The Criminal Interrogation Rules in the Mao Era}

The establishment of the PRC in 1949 was often claimed by Chinese Communists as a total break with China's "feudal" past (Gelatt, 1982). Replacing Confucianism, Marxism-Leninism became the official orthodoxy in guiding social transformation and other facets of national affairs. Notably, Marxism has a poor opinion of law. It was argued that the capitalist law was nothing more than a suppressive tool, which traditionally served the interests of the wealthy minority. When the proletarian revolution succeeds, the state will gradually wither away and law will not be needed (Engels, 1979, 164). In the interim, law was to advance the socialist revolution toward communism and maintain the socialist order (Ren, 1997). More precisely, "law is to be used by the proletariat as a weapon in class struggles against the enemy in order to realize the people's democratic dictatorship" (Peerenboom, 2002, 44).

Owing to the dominance of heavily instrumental understanding of law in the Mao era, the legal restraints imposed on police power in criminal interrogation varied in accordance with the changes in the official attitude toward law and depended, to a large extent, on the political mode toward class struggles.

\subsection{Rules on Police Interrogation: Ups and Downs}

After the CCP seized power in 1949, the majority of laws in force during the Republic were abolished. The Chinese Communists were then beginning to develop a socialist legal system of their own (Ren, 1997). After several years of experimentation, the period 1954 to 1956 saw a brief enlightenment in China's legal development. In 1954, the first Constitution of PRC was promulgated. 
Simultaneously, considerable progress was made in the creation of criminal justice characterized by separate judiciary, procuratorate, and police functions (Gelatt, 1982). Remarkably, efforts were also made to draft a series of criminal procedure rules. According to Article (2:1) of the "Provisional Regulation on the Investigation Procedures for the Procuratorate", promulgated on August 5, 1956, the investigator should inform the accused of his defence rights prior to interrogation. And, during the questioning, the investigator must give the accused sufficient opportunities to explain away the case and make his statements. Although silent on the lawyer's role at the pre-trial investigative stage, the Provisional Code has taken a big step forward by showing serious concern for objective evidence and not just the extraction of confession.

China's progress toward a due interrogation process, however, was interrupted by the Anti-Rightist movement from 1957 to 1958. The Anti-Rightist Movement was a reaction against the "Hundred Flowers" Campaign (19561957), which was initially promoted by Mao to invite criticism of the government and to encourage different views and solutions to national policy issues. But, upon further encouragement, the criticisms became scathing and drifted from Mao's intention of consolidating the socialist leadership and fighting corruption. In July 1957, Mao ordered a halt to the campaign, and shortly thereafter, a series of movements were launched to purge alleged "rightists" within the state (Moise, 1994). Consistent with political priority, the 1956 Provisional Code, which was perceived as "dogmatic", was annulled by the Supreme People's Procuratorate on August 15, 1958. The lawmakers stressed that the crime proofing procedure should not "tie the hands and feet of the investigators". Eventually, in the later promulgated "Provisional Regulation on the Procedure of Handling Criminal Cases for the Procuratorate (draft)"15, many procedural safeguards for the suspect were removed. In particular, the interrogation process became much simplified, with only one legal requirement: the accused should be informed at the beginning of the questioning on the nature and cause of the accusations against him (Art. 14).

After the failure of the Great Leap Forward (1958-1960), during the recovering period in the early 1960s, there were resumed efforts to put the interrogation procedure back on the due process track. Article 4 of the "Provisional Regulations of the Supreme People's Procuratorate on the Examination of Arresting and Prosecution and on Initiating Public Prosecution of Cases", promulgated on August 26, 1963, provided that all investigatory bodies must "base cases on facts and take law as the criterion". This principle was to rely not just on oral statements but on full evidence to ensure just and accurate investigation from which "the guilty would not escape and by which the innocent would not be wronged" (Art. 3). The statute went on to emphasize

${ }^{15}$ Promulgated on March 12, 1959. 
that any person charged with a crime should not be forced to confess (bigongxin, 逼供信) during the questioning process (Art. 24).

However, the storm of Cultural Revolution (1966-1976) quickly swept away the intentions to bring back the interrogation process due, as also justice. In May 1966, alleging that bourgeois elements were permeating the Party and the society at large, Mao ordered that these elements be removed through violent class struggle. The Cultural Revolution that ensued witnessed the dark age of Chinese legal development, when "smashing Gong-Jian-Fa (公检法, policeprocuratorate-judiciary)" became the slogan of the day (Leng, 1982). "Mass violence" against the so-called "class enemies" through widespread incarceration and torture, all without due process, was what they observed (Ren, 1997: 57). For ordinary criminal procedure, there was no more division of functions by investigation, prosecution and trial, and the criminal cases were handled by the court, the procuratorate or the police $(\mathrm{Wu}, 2006)$.

\subsection{On the Ground}

The heavily instrumental nature of the laws, which were periodically altered to control undesirable social groups according to political priorities, no doubt diminished the official's respect for law. Consequently, throughout the first three decades of the People's Republic, Party policy and principles served as the sole guidelines for law enforcement in handling "antagonistic" or "nonantagonistic" contradictions (Ren, 1997). In fact, in the PRC's early administrations, there was not a 'decent' bureaucracy with professionals, such as judges and police officers. Zhu (2007: 554) said that the CCP, long after it seized power in 1949, "remained a revolutionary party in character". In Zhu's opinion, the CCP's strong party organization and ideology during the revolution period (1921-1949) compensated for the lack of a modern bureaucracy, though they impeded the development of such a bureaucracy. For quite a long time after the foundation of the PRC, political loyalty and ideological purity were the most important criteria in selecting government personnel and in promoting cadres, including those in the judiciary and the Public Security (Ren, 1997; Zhu, 2007).

According to the often claimed Party principle, for the purpose of revealing the truth and giving correct treatment ${ }^{16}$, the investigators should be impartial and objective in crime interrogations, and the "people" as also those defined as "the antagonistic classes" should not be coerced into confessing (Wu, 2006, 162). However, lacking a stable legal system, those Party claims are only symbolic manifestations of formalism that merely provide general guidelines for law

\footnotetext{
${ }^{16}$ Mao had a lifelong faith in the ability of human beings to change. He was convinced that individuals with incorrect views could be reformed (Moise, 1994). Therefore, in investigating criminal liabilities, the "factual guilt", especially the offender's criminal motives, should be ascertained in order to accordingly render criminal penalties (Ren, 1997).
} 
enforcement, rather than substantive laws that could impose meaningful restraints on the investigator's questioning powers. Thus, although investigators had no reason to wrongfully persecute suspects, neither had investigators any particular incentive to be vigilant on behalf of suspects. Not to mention being vigilant on behalf of suspects is often potentially inconsistent with or even contradictory to the political agenda of class struggles (Chen, 2000). Free of substantial restraints, the aspiration of the investigator to capture the suspect as a testimonial resource is perfectly 'understandable'. The investigators acknowledged the reason behind their arresting the suspect for questioning. The suspect was, after all, the most efficient possible witness in the investigator's eyes (Cui, 2003). Under this situation, unsurprisingly, there have been frequent reports of brutality in interrogations that clearly amount to cruel, inhuman, and degrading treatment and sometimes even 'torture', under contemporary international law (Chen, 2000).

At this point, one question arises. No doubt, this type of law enforcement must exercise a great deal of discretion so that the players in it could manipulate the interrogation procedure according to the practical needs. To understand this issue, one should not overlook the influence of the traditional Chinese legal culture, which enhanced the rulers' real and symbolic status as the locus of political authority. Although Marxism literally has little in common with Chinese tradition, the influence of Confucianism and legalist values remained a strong driving force in Communist China even without their official recognition (Ren 1997; Peerenboom, 2002).

The Communists, nonetheless, in the process of building a new elite power structure, departed from imperial thrones in stressing family loyalty by displaying higher loyalty to the state. During the early decades of the socialist construction, the informal social control preferred by Confucianism was largely institutionalized through urban household registration system, which linked individuals' residency with their entitlement to social programs. The strict control of population mobility effectuated different social control mechanisms in community, which were primarily responsible for handling local disputes and wrongdoers of minor offences (Whyte and Parish, 1984). When individuals violated rules under the Security Administration Punishment Act ${ }^{17}$, the police had the authority to impose a series of administrative sanctions without formal litigation. Notably, the formal court process was only reserved for offenders who committed serious crimes, especially the so-called class enemies who did not accept and support the Communist leadership (Rojek, 1985). In this manner, the Communist leaders enforced stratifications within the civil society between those who supported the socialist state and those who did not, and thus created a web of status and privilege in the criminal justice sphere to bolster their own legitimacy. Under this arrangement, traditional shaming, moral control, and

${ }^{17}$ Promulgated in October, 1957. 
mutual checks were to some extent as effective as in old times (Rojek, 1985; Lu and Drass, 2002). As a result, in the interrogational rooms, the questioners (i.e. the police, the procuratorate, and the judge), who were both the representatives of the state power and 'moral executors', enjoyed enormous authority. On the contrary, as in imperial times, suspects were still in a socio-culturally disadvantageous position. As such, the contrast in striking power between the two status groups gave the law enforcement huge space for manipulation.

\section{The Criminal Interrogation Rules in the Reform Era}

Upon Mao's death and the subsequent political downfall of the "Gang of four" in 1976, the CCP's devotion to the political struggle against class enemies quickly faded away. Some of the Right-wing leaders who had been purged during the Cultural Revolution were back in position. When the Central Committee of the Communist Party met in the famous Third Plenum in December 1978, the Right-wing group led by Deng Xiaoping could succeed in establishing effective control (Moise, 1994).

The new CCP leadership quickly launched the modernization programme which was summarized as the "Four Modernization"-modernization of agriculture, industry, national defence, and science and technology. In the meantime, many Party leaders, having suffered personally and severely during the lawless period of the Cultural Revolution, were eager to advocate greater reliance on law as a means to preventing the recurrence of such policy-driven excesses. In addition, perhaps more importantly, strengthening the legal system was also considered essential to win back legitimacy both at home and abroad and to provide an orderly environment for economic development (Peerenboom, 2002).

Since then, the new leadership in China made some rapid progress on the legislative front. Notably, the first step it took after the ten year turbulence was the promulgation of the criminal law and the criminal procedure law in 1979. The promulgation of the two laws, no doubt, marked the beginning of the redevelopment of China's criminal justice system (Leng, 1982). Despite remarkable progress, in the ensuing years, legal scholars and criminal justice practitioners noted various deficiencies in the 1979 CPL (Ma, 2003). Specifically, there was a broad consensus that the rights of the suspect were still marginalized by the law (Fu, 1998). In an effort to progress towards judicial democratization and fairness, China revised the 1979 CPL in 1996. 


\subsection{The Criminal Interrogation Rules under the 1996 CPL}

No doubt, structures and concepts influenced by the west had already found their way into Chinese legislation. However, the drafting of legal texts was always greatly influenced by historical experience from which the texts were derived, and in the light of the rationale behind such application. The 1996 CPL is no exception. In general, its content is in no way similar to that of the old imperial codes. Nevertheless, if one compares the central features of contemporary interrogation procedure with those of the imperial 'persuasive' type, it can be seen that many ideas are common to both. The current questioning procedure seems to still focus on fact-finding or factual guilt and to similarly 'oblige' the suspect to respond to the incriminating evidence against him, thereby fostering a high level of self-incriminating statements.

\subsubsection{Circumstances Surrounding Interrogations}

Under the CPL, the police are given powers to interrogate a suspect under two types of situations:

(1) The police may interrogate a suspect after he/she is detained or arrested and taken into police custody (CPL, Art. 65, 72); and

(2) The police may summon a suspect, who need not be detained or arrested, to a designated place in the city or county where he/she stays for interrogation, or the suspect may be interrogated at his/her residence (CPL, Art. 92).

These clauses definitely do not imply that whenever a crime happens the police are empowered to interrogate whomever they please. In the first situation, after a suspect is detained in the detention house, interrogation of the suspect, a typical investigatory act during criminal investigation, would be taken up by the police. In the second situation, because official interrogation invades the suspect's privacy and usually results in a rather prolonged limitation of freedom, it should not be permitted without antecedent justifications. Hence, according to the relevant regulation ${ }^{18}$, the police officer in charge, at or above the county level, shall determine the necessity of questioning. Although necessity operates as a loosely defined threshold, solidly grounded suspicion, rather than slender suspicion, is needed in practice. The law states explicitly that, before the interrogation, the investigator should acquaint himself with the case and its supporting evidence, and then plan and outline the questioning ${ }^{19}$.

\footnotetext{
18 Ministry of Public Security: Regulation on the Procedures of Handling Criminal Cases by Public Security Agencies (Article 173).

19 Ibid. Article 178.
} 
It is also worth noting that, under the $1979 \mathrm{CPL}$, there is no limit on the duration of interrogation through summons. In contrast, according to the 1996 CPL, the duration of interrogation through summons shall not exceed 12 hours, and the police are forbidden from turning a summons interrogation into a de facto detention under the disguise of successive summonses (Art. 92). In essence, the revised CPL wants to limit the initial police investigation to sources of objective information other than of the potentially guilty. Nevertheless, this does not imply that it relaxes its intention of considering the suspect as an important source of testimonial evidence on the whole. Arguably, the revised law devotes considerable attention to the interrogation preconditions to make the questioning effective and productive.

\subsubsection{The "Suspect Speaks" Interrogation}

The Chinese questioning procedure, as mentioned earlier, focuses on factfinding (Wei, 2003, 1-3). Accordingly, in practice terms, the lawmakers asked thus: What procedure would both be fair and best reveal the truth? From this perspective, there was good reason to keep lawyers from speaking on behalf of the accused: truth probably would not so well be discovered from the artificial defense of others speaking for the suspect. Hence, under the 1979 CPL, questioning by the police was conducted without legal advice and without the presence of a lawyer. The 1996 CPL improved the rights of the suspect in various perspectives, but did not include the right to have a lawyer by his side during police questioning. Only after the first interrogation or from the day on which compulsory measures are adopted, can the suspect have the right to see his attorney (CPL, Art. 96).

Consequently, the suspect himself has to speak in his own defence and respond to the evidence as given by the questioner. In contrast to the jurisprudence of the European Court of Human Rights (ECtHR), which requires suspects to make unfettered waivers to the right of remaining silent whenever they respond to official inquiry ${ }^{20}$, in China, they are not free to decide whether to submit to the interrogation process in general. A suspect is expected to answer questions asked by investigators truthfully and can refuse to respond to only those questions that are irrelevant to the case (CPL, Art. 93). Although there is no provision in the law as to the consequences that follow from a suspect's silence, such as the fact finder drawing unfavourable inferences from a passive reaction, the real concern of continued silence is that such adverse inferences will, in fact be drawn, consciously or unconsciously, by the interrogators ${ }^{21}$ (Chen and Lan, 2008). Clearly, if the suspect refuses to respond, the defensive function

\footnotetext{
${ }^{20}$ ECtHR 29 November 1996, Saunders v. The United Kingdom, (no. 43/1994/490/572), § 55.

${ }^{21}$ Because the police officers believe that if the case against a suspect is false, the suspect is likely to speak up and object, and if he remains silent rather than talking, this could only be because he has something to conceal or, because he is unable to deny the truth of the evidence, which the police have against him (Cui, 2001).
} 
will merge with the testimonial function in the current questioning process, and his suspicion could appropriately increase.

As truthfulness of the statements elicited cannot be guaranteed, prohibitions of torture and other forms of inhuman practices are not open to question (CPL, Art. 43). Moreover, the CPL pays special attention to the types of questions that need to be asked sequentially during the questioning. According to Article 93 of the CPL, "when interrogating a suspect, the investigators shall first ask the suspect whether or not he has committed any criminal act, and let him state the circumstances of his guilt or explain his innocence; then they may ask him questions". The Chinese legal principle maintains that the suspect's defence comes first because it is primarily designed to prevent the police from proceeding on the premise that the suspect is guilty (Ma, 2007). Whatever the proclaimed rationale, there is little doubt that this arrangement is advantageous to the investigation. The police, as the imperial magistrates, may sit back at the beginning and hope that damaging evidence would come out if the concocted story of a guilty suspect crumbles on subsequent disclosure of evidence. Such damaging evidence may be in the form of inconsistency in the account given by the suspect, thereby demonstrating the lies told by the suspect, or in the form of failure to answer the questions posed by the police. All this evidence could be used either to encourage suspects to confess or against them at their trials (Wei, 2003).

\subsection{Law in Practice and Social Context}

In short, the Chinese law no longer considers confession or voluntary admission of guilt as an essential legal component of ending a crime investigation, while it still encourages suspects to participate in police questioning as a testimonial source. Factual guilt, not legal guilt, is the key word here. The criminal procedure, in general, focuses more on the need to prevent unreliable statements, than on the restraining of police interrogation powers. This perspective is reflected in a strong emphasis on proper preparation prior to the questioning, in the limited right to counsel at the pre-trial stage and in the "suspect speaks" interrogation model that seeks to gather extensive, detailed information and factual accounts from the suspect. Apparently, this model presupposes that the interrogator, being impartial and professional, can be largely trusted to guarantee both the quantity and the quality of information that the interviewee can potentially provide, which are essential to truth-finding.

However, such expectations do not bear out in practice. Many Chinese scholars, relying on different sources, such as interviews with present and former law enforcement officers, or individual field observation, have made the alarming assertion that the problem of confessions produced by xingxun (刑讯) physical force or psychological duress - is widespread in police questionings in China (Wu \& Vander Beken, 2010). In addition, Cui (2003: 26) comments thus on 
the fatal effect of police coercion on the reliability of evidence: "Although confessions elicited by xingxun are not always false, wrongful convictions, with no exception, are all because of xingxun".

Literature on the causes of police-coerced confessions in criminal interrogations covers a wide range of topics in terms of the levels of analysis. Notably, besides loopholes or shortcomings in the law and the ineffective institutional mechanisms for controlling state powers, the influence of traditional cultural values is also considered a reason by some socio-legal studies: while coerced confession is absolutely cruel, its exercise depends at almost every level on many forms of cooperation and consensus (Lin, Yu and Zhang, 2006; Lin, Zhao and Huang, 2006). To further understand the social and cultural background because of which the pernicious interrogation practices persist, it is evident from the foregoing discussion that one must consider the relationship between the interrogator and the suspect in the crime investigation. An analysis of this relationship, at both macro and micro levels, is presented below.

\section{The Paternalistic Criminal Justice System}

First, on a macro level, China is still a paternalistic state in which the law enforcement is likely to have the real and symbolic status as the protector of anonymous collective interests, such as public security or social stability, engendering a tendency to ignore concrete interests of individual suspects and to lose sight of the power abuse by the investigators within the sphere of crime and justice.

Although the CCP has made a series of mistakes since it came into power in 1949, in Peerenboom's (2002:42) view, "the image [of the Chinese government] remains the same: the father, knowing what is best, takes care of his children". Today, the CCP leadership, to a large extent, decides what is best for the Chinese society and takes ameliorative actions to solve contemporary problems. In the last three decades, the state's economic policy proved to be spectacularly successful, improving the Chinese citizens' living conditions in a relatively short run while at the same time creating a high rate of long-term economic growth (Peerenboom, 2006). The Chinese government clearly understands the importance of maintaining stability which constitutes a prerequisite for economic growth and for the CCP's continuous legitimacy and popularity. Hence, to satisfy the practical need for more effective social control, the current Chinese criminal justice system altered the principles of law and punishment under the Mao era in some aspects and adopted Confucianism and legalist legacies in others. As in the pre-reform era, the police, without court approval, have the authority to impose administrative sanctions on individuals guilty of minor crimes and public order violations. Wrongdoers are dealt with by the criminal justice system only when serious offences were involved. Although the 
police's administrative power that was once used to control the urban transients has been eliminated under the $1996 \mathrm{CPL}$, their power for detaining criminal suspects was extended. No doubt, Chinese police, compared with those of Western law enforcement, have greater authority and power over ordinary citizens (Biddulph, 1993; Ma, 1997).

Apart from political agenda, another crucial factor in further reinforcing the authority of the police lies in social changes within the Chinese civil society in the reform era. As China has been moving toward a market economy since 1978, the traditional informal social control that relied on rigid household registration and employment structure has declined (Dutton, 2000). Concurrently, increased mobility has resulted in a class of "floating population" (liudongrendou, 流动人口 ), who are often blamed for urban problems, including the soaring crime rates. Given that transients have no attachment, commitment, or involvement in communities, subjecting them to stronger formal control by the criminal justice system is deemed necessary by urban citizens to curtail crimes (Lu and Drass, 2002). Moreover, as police officers, following the "mass-line" in policing, actually live and work in a neighbourhood for a long time, most Chinese citizens do not view the police as a force limiting their freedom, but as a service resource they can rely on (Jiao, 2001). As a result, the formal law enforcement is shouldering more responsibility for solving crimes, thus reinforcing itself in both real and symbolic senses (Wong, 2001).

Importantly, within the paternalistic state, as a legal professional group, Chinese defence counsels have not been a prominent force in balancing state powers. In imperial China, the status of scriveners, who were labelled as "litigation tricksters", was regarded low, because the pursuit of self-interest by adverse litigation, as it signifies one's refusal to take responsibilities for one's action, is at odds with the paramount virtue of social harmony (Yu, 2002; Clark, 2008). Under socialist China, the state belongs to the people; so, lawyers are not expected to oppose the state in a criminal investigation but shoulder dual responsibilities of not only protecting the rights of the suspect, but also, more importantly, helping the state to seek the truth (Lu and Miethe, 2002; Clark, 2008). In the absence of an officially recognized legal profession for millenniums, the use of legal counsel is rather new to the Chinese criminal justice system. Until recently, more than 70 percent of the criminal cases were processed without lawyers appearing in court on behalf of the defendants $(\mathrm{Wu}, 2006)$. In this context, Lu and Miethe (2002: 277) observed thus: "contrary to the image of an advocate of the defendant, Chinese attorneys under the reform policies still play a major role in legitimizing the current legal system." Chinese counsels, even those seasoned attorneys, know how to obtain the best results for their clients by not being "combative" or "arrogant", but being "deferential" and "submissive" during the criminal proceedings (Liu and Scymour, 1998). 
Undoubtedly, the current paternalistic procedure structure in which the police have the sole responsibility for implementing procedural safeguards, if frequently unchallenged, is dangerous. Though coercive questioning, an extreme means to get objective evidence, implies weakness of the daily operations of the police ${ }^{22}$, it can also be attributed to the "system" of criminal justice that allows it to exist. For law enforcement as a whole, by relying heavily on confession to solve crimes, it is able to divert the available funds to other arguably more productive uses ${ }^{23}$.

\section{Interrogational Paternalism}

Second, on a micro level within the interrogation space, the relationship between the interrogator and the suspect has been and continues to be paternalistic. The attitude of criticizing wrongdoers for their unwillingness to repent for and admit to the crime facts, which has driven from the familist or paternalism tradition, continues to offer plenty of psychological comfort to the police. Although the "open-door" policy has increased individualism in China, to a large extent, Confucian doctrines of filial piety and family loyalty still strongly influence the modern Chinese family relationships (Whyte and Parish, 1984). It was suggested that the Chinese family often dominates the individuals by forcing them to come to terms with family values and tradition $(\mathrm{Lu}$, Zhang and Miethe, 2002). With such moral cultivation, according to Fairbank (1987:31-32), "Chinese well habituated to the family system have been prepared to accept similar patterns of status in other institutions, including the official hierarchy of the government". Hence, in the interrogation room, the suspect's submissive and honest attitude seems to be considered legitimate and morally valid by the interrogators. In addition, the societal view on crime and wrongdoers gives law enforcement "additional moral legitimacy to take measures to coerce confessions and press for repentance" (Ren, 1997, 132). As a survey conducted in 2006 shows, the public's attitude towards police pernicious interrogation practices is tolerant, and even supportive (Lin, Zhao and Huang 2006: 133-4).

\footnotetext{
${ }^{22}$ Specifically, the daily operations of the police are undermined by a shortage of budget (Zhu, 2006; Chen, 2007) and poorly trained police officers (Wang 2006); the police force is undersized and functions by using underdeveloped investigative methods (Zuo and Zhou 2002; Wu 2008).

${ }^{23}$ Chen (2007: 59) argues that the importance of increasing national investment in criminal investigation has never been fully recognized by the Chinese government. Since the advent of an open economy and a reform policy, the government's financial input in criminal investigations, concerning personnel or technology, has not increased concurrently with the significant rise in crime as well as the changes in crime patterns. Owing to limited budget, some forensic techniques of crime procedure, like DNA testing, cannot be employed (Chen, 2007).
} 


\section{Conclusion}

Even a cursory review of the interrogation rules of the imperial, Mao and reform eras will suffice to demonstrate just how remarkable has been China's criminal justice transformation. Notwithstanding the many shortcomings in the current interrogation procedure, dramatic progress has been made in creating a fair questioning process that not only addresses the concern over factual accuracy of statements but also emphasizes the fairness of the manner in which they are obtained. Most strikingly, though police torture in criminal interrogation is part of the dim and dark history of Chinese criminal law, today's China, by virtue of the provisions of criminal procedure and criminal law, forbids the practice wherein the suspect or the accused should be forced, by actual or metaphorical "arm-twisting", to respond to police inquiries. Nonetheless, the result might not always be what the law intends to achieve: numerous Chinese scholars observed that confession obtained by extensive use of psychological and physical coercion is still a pervasive problem in crime investigations in China today. Several views were offered on the factors that contributed to this phenomenon.

This paper offers an alternative perspective on the evolution and operation of Chinese interrogation rules, besides positing more nuanced explanations for the prevalence of police coerced confession in China. The present historical analysis reveals that the imperial, social context which once morally legitimized judicial torture is still very much alive today. More precisely, historically, the Chinese leadership, through the interplay between Confucianism's moral standards and legalist bureaucracy, relied heavily on informal means to maintain social order and settle disputes, and established a powerful, minimalist law enforcement authority which was responsible for only conflicts that could not be solved by informal mechanisms, and for serious crimes. On the whole, this social control model failed to adequately address the need to protect individuals against law enforcement interrogation practices that were abusive or overreaching, and therefore indirectly contributed to the prevalence of police-coerced confession both in the past and in the present.

Considering the future reforms within the current Chinese social context, two factors seem to be unconducive for the right to remain silent and the privilege against self-incrimination. First, Chinese lawmakers under the reform era continued to emphasize the importance of being honest in police interrogation. Article 93 of the 1996 CPL provides that "the criminal suspect shall answer the investigators' questions truthfully". This legal requirement has drawn heavy criticism from contemporary legal scholars ( $\mathrm{He}, 2006 ; \mathrm{Wu}, 2006)$, who claim that it denies the suspect's basic rights to reach an autonomous decision when called upon to answer criminal allegations. This is viewed as the essence of the right to remain silent in Western culture (Jackson, 2009; Wu, 2011). However, at this point, it should be noted that Chinese law was embedded in an altogether 
different ideological context than the one that gave rise to the right to remain silent in the West. As already seen, the imperial Chinese law is largely moralistic in nature. Since the Han dynasty, Confucian's moral standards, particularly those dealing with contrition, patriarchal relationships and familial obligations, started to become a part of the content of law, and legalist's reward and punishment machineries became the instruments for executing such content. In the reform era, the attitudes of being honest about one's misconduct and being submissive to authority continued to be reinforced by Chinese familism. Hence, the better way to comprehend the above mentioned provision is not to consider it a manifestation of caprice on the part of the present Chinese leadership, but rather to recognize it as an expression of the inherent Chinese legal attitude which the Chinese lawmakers want to respect and enhance. This is not to say that other external pressures of the kind mentioned at the beginning of this article, such as the pressure on the PRC to comply with the "universal norms", for instance the privilege against self-incrimination, will not make the content of the new laws profoundly different from that of the past, difficult as this may be to accomplish. So long as the familist and societal view of crime and wrongdoers held sway, the real question is whether the new content can overcome hoary practices, values and interpretations.

Second, complicating the task of legal reformers who wish to establish the right to remain silent, China is, to a large extent, still a paternalistic state in which the law enforcement is likely to have the real and symbolic status as the protector of anonymous collective interests, such as social stability, engendering a tendency to ignore concrete interests of individual suspects within the sphere of crime and justice. It is still debatable whether China will develop a robust civil society in which the citizens will strike a similar balance between the concerns for individual rights, and for the interests of families, communities and the nation, considering the continuity of the political and social control traditions in the Chinese society. The CCP, certainly, will not fall from power in the near future. Moreover, the familism values of bonding individuals to the family, community, and state has enabled the Communist leadership to continue its traditional role in manipulating those conventional social control variables either by reinforcing their traditional functions or by redirecting their impacts on individual citizens.

At this point, the Chinese government, whose image has been badly tarnished by police torture, both at home and abroad, does not lack the motivation to eliminate coerced confessions. In addition, the desire for modernization of China's political and legal system will inevitably reshape the law and social control mechanisms. To be sure, the vicissitudes along the road to social development are never predetermined; so, it may be difficult at this point to foresee the impact of state policies on social relationships. Nevertheless, given that the average citizen's indifference to the plight of criminal suspects is largely due to the high crime rates as a result of the weakened informal social control, 
particularly on urban transients after the legal reforms, the best chances for a better protection of a suspect's rights and the elimination of coerced confession lie in narrowing down the yawning social cleavage rather than widening it. There is no doubt that Chinese lawmakers can find a lot of wisdom in the early Confucian philosophy.

As Posner (1993) rightly argues, laws are not abstract, sacred entities, but socially determined goads for shaping behaviour so as to conform to society's values. Indeed, there can be no wisdom in the choice of a path unless we know where it will lead. As we have seen in the first section, the values of community relationship and shaming serve as the basis of social inclusion in the Chinese communitarian society. Those values are also supportive of an ethical approach to investigation and a cooperative interviewing style in police questioning. Therefore, in any event, many of the most pressing obstacles for the implementation of fair interrogation standards have nothing to do with the early Confucian philosophy. Rather, they are institutional in nature. Ultimately, the key to the future realization of interrogation fairness is power. How is power to be controlled and allocated in the questioning room? According to Peerenboom (2004: 137), "[i]t is possible that the ruling regime [of China] will be forced to accept limitations on its power as a condition for staying in power." Hence, there are reasons to believe that the issue of power can be resolved in favour of rule of law and law will come to impose ever more meaningful restraints on law enforcement in the near future.

\section{References}

Alford, W. P. (1984). Of Arsenic and Old Laws: Looking Anew at Criminal Justice in Late Imperial China. California Law Review, 72(6), 1180-1256.

Bary, W. T. (1995). The "Constitutional Tradition" in China. Columbia Journal of Asian Law, 9, 7-34.

Bedau, H. A., \& Radelet, M. L. (1987). Miscarriages of Justice in Potentially Capital Cases. Stanford Law Review, 40(1): 21-179.

Biddulph, S. (1993). Review of Police Powers of Administrative Detention in the People's Republic of China. Crime and Delinquency, 39 (3), 337-354.

Brewer, N., \& Williams, K. D. (2005). Psychology and law: An empirical perspective. New York: Guilford Press.

Chang, Y. (2004). Courtroom Questioning as a Culturally Situated Persuasive Genre of Talk. Discourse E Society, 15(6), 705-722. 
Chen, R. H. (2006). To Provide For New Rights or To Strengthen Remedies? [zengliequanli haishi jiaqiangjiuji]. Global Law Review, 161, 530-536.

Chen X. (2004). Social and legal control in China: a comparative perspective. International Journal of Offender Therapy and Comparative Criminology, 48 (5), 52336.

Chen, Y. S. (2000). Against Torture - The Rule of Law and Human Rights Protection in Modern China. Bei Jing: Social Science Academic Press.

Chen, Y. S. (2007). A Perspective of China's Criminal Misjudgment [woguo xingshiwupan wentitoushi]. China Legal Science, 137, 45-61.

Chen, G., \& Lan, H. H. (2008). The Deadlock of Criminal Interrogation [lun zhenchaxunwen jiangju]. Journal of Jiangxi Public Security College, 122, 73-76.

Clark, G. (2008). An Introduction to the Legal Profession in China in the Year 2008. Suffolk University Law Review, 41 (4), 833-850.

Cui, M. (2001). Examining and Rethinking of the Privilege of Silence and the Police Privilege of Inquiry [guanyu chenmoquan yu jinghca xunwenquan de sikaoyufansi]. Journal of Chinese People's Public Security University, 94, 48-58.

Cui, M. (2003). Holding Back Interrogational Torture [zailun ezhi xingxunbigong]. Journal of Zhejiang Police College - Public Security Science Journal, 76, 24-29.

Dikötter, F. (2002). Crime, Punishment and the Prison in Modern China. London: C. Hurst \& Co. (Publishers) Ltd.

Dutton, M. (2000). The end of the (mass) Line? Chinese policing in the era of the contract. Social Justice, 27(2), 61-105.

Engels, F. (1979). Letter to van Patten, 18.4.1833. In M. Cain \& A. Hunt (Eds.), Marx and Engels on Law (pp. 164-165). London: Academic Press.

Fu, H. L. (1998). Criminal Defence in China: The Possible Impact of the 1996 Criminal Procedural Law Reform. China Quarterly, 153, 31-48.

Fung, H. (2006). Affect and Early Moral Socialization: Some Insights and Contributions from Indigenous Psychological Studies in Taiwan. In U. Kim, K. K. Hwang, \& K. S. Yang (Eds.), Indigenous and Cultural Psychology: Understanding People in Context (pp. 175-196). Boston, MA: Springer Science + Business Media. 
Jiang, S., Lambert, E., and Wang, J. (2007). Correlates of Formal and Informal Social/Crime Control in China: An exploratory study. Journal of Criminal Justice, 35(3), 261-271.

Jiao, A. Y. (2001). Police and Culture: A Comparison between China and the United States. Police Quarterly, 4(2), 156-185.

Gelatt, T. A. (1982). The People's Republic of China and the Presumption of Innocence. Journal of Criminal Law and Criminology, 73(1), 259-316.

Grant, G. (1989). The Family and Social Control: Traditional and Modern. In R. J. Troyer, J. P. Clark,\&D. G. Rojek (Eds.), Social control in the People's Republic of China (pp. 17-25). New York: Praeger.

Gudjonsson, G. H. (1992). The psychology of interrogations, confessions, and testimony. Wiley series in psychology of crime, policing, and law. Chichester, West Sussex, England: Wiley.

Gudjonsson, G. H. (1994). Investigative interviewing: recent developments and some fundamental issues. International Review of Psychiatry, 6(2): 237-245.

He, Y. J. (2006). Plea Bargaining and Interrogational Torture [cong biansujiaoyi kan xingxunbigong]. Journal of Jiangxi Public Security College, 104, 93-96.

Helmholz, R. H. (1997), The Privilege Against Self-Incrimination: Its Origins and Development. Chicago: University of Chicago Press.

Hu, H. C. (1944). The Chinese Concepts of "Face". American Anthropologist, $46(1), 45-64$.

Hu, M. (2007). Extorting Confessions by Torture: from the Perspective of Criminal Policy [xingshizhengce xia de xingxunwenti]. Global Law Review, 110, 1522.

Jackson, J. (2009). Autonomy and Accuracy in the Development of Fair Trial Rights', University College Dublin Law Research Paper No. 09/2009. Available at SSRN: http://ssrn.com/abstract $=1407968$

Johnson, W. (1995). Status and Liability for Punishment in the T'ang Code. Chicago-Kent Law Review, 71, 217-229.

Kaempfer, I. (2006). Chinese Traditional Values and Human Rights: An Empirical Study among Students in Shanghai. Doctoral dissertation, University of Fribourg, Fribourg, Switzerland. http://ethesis.unifr.ch/theses/downloads.php?file=KaempferI.pdf 
Kitayama, S., Markus, H. R., \& Kurokawa. M. (2000), 'Culture, Emotion, and Well-being: Good Feelings in Japan and the United States', Cognition and Emotion, 14 (1): 93-124.

Langbein, J. H. (1977). Torture and the Law of Proof: Europe and England in the Ancien Régime. Chicago: University of Chicago Press.

Langbein, J. H. (2004). The Legal History of Torture. In Levinson, S. (Eds.), Torture: A collection (pp. 93-103). Oxford: Oxford University Press.

Leng, S.-C. (1982). Criminal Justice in Post-Mao China: Some Preliminary Observations. Journal of Criminal Law and Criminology, 73(1), 204-237.

Leo, R. A. (1992). From coercion to deception: the changing nature of police interrogation in America. Crime, Law and Social Change, 18, 35-39.

Leo, R. A. (2008). Police Interrogation and American Justice. Cambridge, Mass: Harvard University Press.

Lin, W. P. (2005). Finding a Balance Between 'Crime Control' and 'Human Rights Protection' [tanqiu dajifanzui yu baohurenquan de pinghdianxingshisusongzhong dangshiren hefaquanyiwenti yantaohui zongshu]. Policing Studies, $124,90-94$.

Lin, L. H., Yu, T. \& Zhang, C. (2006). Survey Report: Social Cognition of Extorting Confessions by Torture-The Police [xingxunbigong shehuirenzhi baogao-jingcha juan]. Law Review, 139, 123-140.

Lin, L. H., Zhao, Q. L., \& Huang, Q. H. (2006). Survey Report: Social Cognition of Extorting Confessions by Torture -The General Public [xingxunbigong shehuirenzhi baogao-minzhongjuan]. Law Review, 138, 117-135.

Liu, Y. D., \& Seymour, J. D. (1998). Guest Editors' Introduction. Chinese Law and Government, 31 (3), 3-7.

Lu, H., \& Drass, K. (2002). Transience and the disposition of theft cases in China. Justice Quarterly, 19 (1), 69-96.

Lu, H., \& Miethe, T. D. (2002). Legal Representation and Criminal Processing in China. British Journal of Criminology, 42 (2), 267.

Lu, H., \& Miethe, T. D. (2003). Confessions and Criminal Case Disposition in China. Law and Society Review, 37(3), 549-578. 
Lu, H., Zhang, L., \& Miethe, T. D. (2002). Interdependency, Communitarianism and Reintegrative Shaming in China. The Social Science Journal, 39, 189-202.

Ma, H. H. P. (1987). The legalization of Confucianism and its impact on family relationships. Washington University law quarterly, 65(4), 667-679.

Ma, H. J., \& Li, B. T. (1999). Procedure Instrumentalism and Interrogational Torture [chengxu gongjuzhuyi yu xingxunbigong]. Law Journal of Shanghai Administrative Cadre Institute of Politics and Law, 63, 63-65.

Ma, J. H., \& Peng, M. (2006). Illegal Interrogation: A Research on Empirical Viewpoint-An Analysis Mainly on the Model of S Province [feifashenxun: yige shizhengjiaodu de yanjiu - yiSsheng wei zhuyaoyangben de fenxi]. Journal of Fujian Public Safety College, 92, 22-29, 42.

Ma, Y. (1997). The Police Law 1995: Organization, Functions, Powers and Accountability of the Chinese Police. Policing, 20 (1), 113-135.

Ma, Y. (2003). The Powers of the Police and the Rights of Suspects under the Amended Criminal Procedure Law of China. Policing: An International Journal of Police Strategies \& Management, 26(3), 490-510.

Ma, Y. (2007). A Comparative View of the Law of Interrogation. International Criminal Justice Review, 17(1), 5-26.

MacCormack, G. (1987). Liability of Officials under the Tang Code. Hong Kong Law Journal, 17, 142-162.

Moise, E. E. (1994). Modern China: A History. New York: longman.

Ning, J. (2002). Economic Analysis of Torture in Law Enforcement [xunwen de jingjixue -dui xingxunbigong de jingjifenxi]. China Economic Quarterly, 4, 985-998.

Peerenboom, R. (2002). China's long march towards rule of law. Cambridge Press.

Peerenboom, R. (2004). Out of the Pan and into the Fire: Well-Intentioned but Misguided Recommendations To Eliminate All Forms of Administrative Detention in China. Northwestern University Law Review, 98 (3), 991-1104.

Peerenboom, R. P. (2004). 'Competing Conceptions of Rule of Law in China', in Peerenboom, R. P. ed., Asian discourses of rule of law: Theories and implementation of rule of law in twelve Asian countries, 113-145. France, and the U.S. London: Routledge. 
Peerenboom, R. (2006). Law and Development of Constitutional Democracy: Is China a Problem Case?. The Annals of the American Academy of Political and Social Science, 603(1), 192-199.

Posner, R. A. (1993). The problems of jurisprudence. Cambridge, Mass: Harvard University Press.

Ren, X. (1997). Tradition of the Law and Law of the Tradition: Law, State, and Social Control in China. Westport, Conn: Greenwood Press.

Ren, X. L. (2007). The Barriers to the Application of Synchronous Recording of Interrogation [xunwen tongbu luyinluxiang zhidu zai woguo shishi de zhangai]. Journal of Shandong Police College, 94, 65-68.

Rickett, W. A. (1971). Voluntary Surrender and Confession in Chinese Law: The Problem of Continuity. The Journal of Asian Studies, 30(4), 797-814.

Rojek, D. (1985). The Criminal Process in the People's Republic of China. Justice Quarterly, 2(1), 117-125.

Terrill, R. J. (2003). World Criminal Justice Systems: A Survey. Cincinnati, OH: Anderson Pub.

Tu, W. (1979). Humanity and self-cultivation: Essays in Confucian thought. Berkeley: Asian Humanities Press.

Van Kessel, G. (1998). European Perspectives on the Accused as a Source of Testimonial Evidence. Western Virginia Law Review, 100, 799-845.

Wan, Y. (2006). A Reevaluation of China's Interrogation Process in Investigation Stage [zhencha xunwen chengxu de pipanxing chongsu]. Journal of Anhui University (Philosophy and Social Sciences), 439, 67-73.

Wang, M. (1997). The Methods and Significance of the Modification of Laws in the Late Qing Dynasty [lun qingmo xiulv de fangfa yu yiyi]. Journal of Nanjing Normal University (Social Science Edition), 95, 37-41.

Wang, Z. C. (2006). Tackling the Persistent Ailment of Police Interrogational Torture [zhiyizhi xingxunbigong zheyi wanzheng]. People's Procuratorial Semimonthly, 1199, 15-21.

Wei, P. (2003). Criminal Investigation and Interrogation. Beijing: China University of Political Science and Law Press. 
Whyte, M. K., \& Parish, W. L. (1984). Urban Life in Contemporary China. Chicago: University of Chicago Press.

Wilson, R. (1980). Conformity and deviance regarding moral rules in Chinese society: A socialization perspective. In A. Kleinman \& T. Lin (Eds.), Moral and abnormal behavior in Chinese culture (pp. 117-136). Dordrecht: D. Reidel.

Wilson, R. (1981). Moral Behavior in Chinese society: A theoretical Perspective. In R. Wilson, S. Greeenblatt, \& A. Wilson (Eds.), Moral behavior in Chinese society (pp. 1-20). New York: Praeger.

Williamson, T. M. (1993). From interrogation to investigative interviewing; strategic trends in police questioning. Journal of Community \& Applied Social Psychology, 3(2): 89-99.

Windrow, H. (2006). A Short History of Law, Norms, and Social Control in Imperial China. Asian-Pacific Law \& Policy Journal, 7, 244-301.

Wong, K. C. (2001). Community policing in China: Philosophy, law and practice. International Journal of the Sociology of Law, 29(2), 127-147.

Wu, D. H. (2006). Role, Situation and Sustainability - Analyzing Interrogational Torture from a Socio-Legal Perspective [juese, qingjing yu shehuirongrenfashehuixue shiyezhongde xingxunbigong wenti]. Peking University Law Journal, 104, 147-169.

Wu, J. K. (2008). The Permitting Study of Duplicity Interrogating [qipianxing xunwen rongxuxing yanjiu]. Journal of Jiangxi Public Security College, 118, 28-35.

Wu, W. (2011). Interrogational Fairness Under The European Convention On Human Rights. International Journal of Law, Crime and Justice, 39, 37-59.

Wu, W., \& Vander Beken, T. (2010). Police Torture in China and its Causes: A Review of Literature. The Australian and New Zealand Journal of Criminology, 43(3), 557-579.

Yu, P. (2002). Glittery Promise vs. Dismal Reality: The Role of a Criminal Lawyer in the People's Republic of China after the 1996 Revision of the Criminal Procedure Law. Vanderbilt Journal of Transnational Law, 35 (3), 827-865.

Zhe, F. M. (2005). The Exclusionary Rule for Involuntary Oral Statements - From the Perspective of Torture [feiziyuankougong de paichuguize-cong xingxunbinggong jiaodu de fenxi]. Legal Forum, 96, 26-29. 
Zhu, S. L. (2005). The tragedy of Dou E: the problem of Evidence in Traditional Chinese Justice [doue de beiju - chuantong sifazhong de zhengjuwenti]. Social Science in China, 68, 96-108.

Zhu, S. L. (2007). Political Parties in China's Judiciary. Duke Journal of Comparative \& International Law, 17(2), 533-560.

Zhu, X. Q. (2006). Personal Reflections on Lawyer's Presence during Criminal Interrogations [zhenchaxunwenshi lvshi zaichang zhiwojian]. People's Procuratorial Semimonthly, 1210, 15-18.

Zu, W. (2008). Primary Rules on Criminal Evidence in Ancient China and its Theoretical Basis [zhongguo gudai jugongdingzui xingshizhengju shouyaoguize ji lilunjiexi]. Law \& Social Development, 79(1), 42-62.

Zuo, W. M. (2005). Elimination Interrogational Torture by Legalizing Investigation Works [tuijin fazhihuajianshe ezhi xingxunbigong]. People's Procuratorial Semimonthly, 1178, 7-8.

Zuo, W. M., \& Zhou, H. B. (2002). From Legal to Illegal: An Analysis of Interrogational Torture in Context [conghefa daofeifa: xingxunbigong de yujingfenxi]. Law Science, 552, 31-40. 